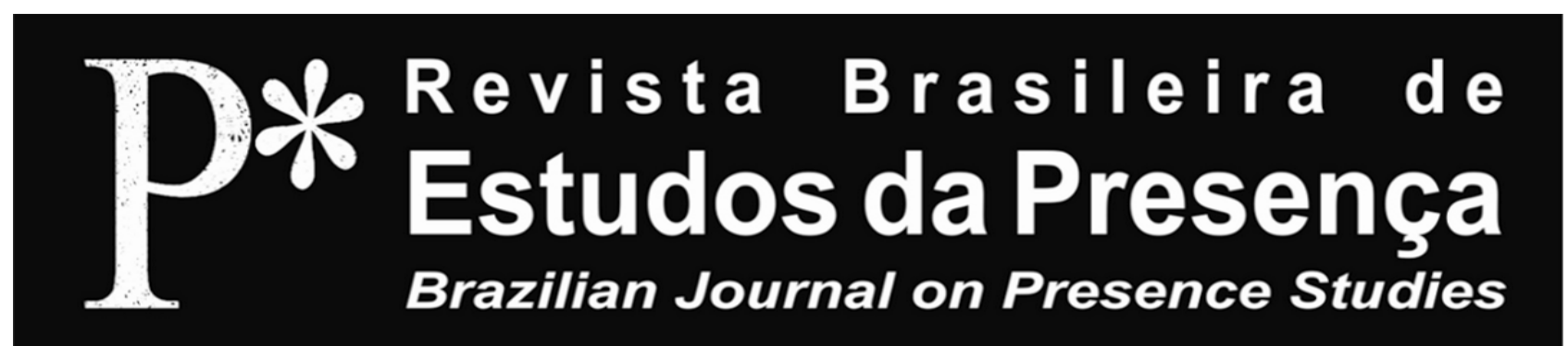

PERFORMANCE AND ANTHROPOLOGY

E-ISSN 2237-2660

\title{
Anthropology of Performance or Anthropology of Contemporary Theatre?: ethnographic remarks on companhia brasileira de teatro and PROJETO bRASIL
}

Cauê Krüger'
'Pontifícia Universidade Católica do Paraná - PUCPR, Curitiba/PR - Brazil

ABSTRACT - Anthropology of Performance or Anthropology of Contemporary Theatre?: ethnographic remarks on companbia brasileira de teatro and PROJETO bRASIL - Based on anthropological and ethnographical fieldwork research with companhia brasileira de teatro this article points to some limits of a universalist and orthodox anthropology of performance. It sustains, alternatively, one anthropology of contemporary theatre, dealing with concepts such as drama, performance and dramaturgy as research realms, able to express desires, expectancies, and meanings disputes enrolled in the artistic process. This study reveals how performative theatre, metadiscursive and de-dramatizing strategies lead to polysemic and reflexive scenes that provide critical discourses, viewpoints shifts and encourage sensibility for alterity.

Keywords: Anthropology of Performance. Anthropology of Theater. Contemporary Dramaturgy.

RÉSUMÉ - Anthropologie de la Performance ou Anthropologie du Théâtre contemporain?: considérations sur companbia brasileiva de teatro et PROJETO bRASL - A partir d'une recherche de terrain anthropologique et ethnographique avec companhia brasileira de teatro cet article démontre des limites de l'anthropologie de la performance de façon universaliste et orthodoxe. On propose, autrement, une anthropologie du téâtre contemporain considèrent des notions de drame, de performance et de dramaturgie comme des univers d'investigation capables d'exprimer des désirs, des aspirations et des disputes de sens dans le processus artistique. Cette étude démontre comme l'emploi du théâtre performatif et des stratégies métadiscursives et de dédramatisation ont résulté en des scènes polysémiques, réflexives et capables de soutenir des discours critiques, de changer des points de vue et de sensibilizer pour l'altérité.

Mots-dés: Anthropologie de la Performance. Anthropologie du Théâtre. Dramaturgie Contemporaine.

RESUMO - Antropologia da Performance ou Antropologia do Teatro Contemporâneo?: notas etnográficas a propósito da companbia brasileira de teatro e do PROJETO bRASIL - Tendo por base um trabalho antropológico e etnográfico junto à companhia brasileira de teatro, o presente artigo pretende apontar para os limites de uma antropologia da performance ortodoxa e universalizante. Propóe, alternativamente, uma antropologia do teatro contemporâneo tomando as noçóes de drama, performance e dramaturgia como universos investigativos capazes de apontar para desejos, expectativas e disputas de sentido envolvidas no processo artístico. O estudo demonstra como o uso do teatro performativo, de estratégias metadiscursivas e de desdramatizaçáo resultaram em cenas polissêmicas, reflexivas, capazes de promover discursos altamente críticos, suscitar a modificaçáo de pontos de vista e sensibilizar para a alteridade.

Palavras-chave: Antropologia da Performance. Antropologia do Teatro. Dramaturgia Contemporânea. 
In the early 1990s, in a paper promoting the recognition of a state of the art on the anthropology of theater and the spectacle, the anthropologist William Beeman featured studies by social historians, sociologists, and folklorists in the analysis of theater as a widely consolidated Western institution. Likewise, he pointed to the frequent use of anthropological methods and concepts by theater scholars and was led to the surprising conclusion that "[...] little work on Western performative traditions has been undertaken by anthropologists" (Beeman, 1993, p. 376). More than a quarter of a century later, this diagnosis still seems pertinent: although the fields of ethnocenology ${ }^{1}$, anthropology of theater ${ }^{2}$, and performance anthropology ${ }^{3}$ have consolidated, there are few anthropologists devoted to ethnography or to participant observation of conventional theater. This text intends to contribute to the development of an anthropology of contemporary theater which is just beginning to blossom ${ }^{4}$; our point of departure is ethnographic research on the companhia brasileira de teatro.

\section{From Ritual to Theater}

The reason for Beeman's astonishment becomes more evident when we go over the list of anthropological reflections on performing arts since the beginning of the 20th century. As expected, the studies of the ritual provided the earliest approximation of the two fields. Besides the remarkable works of Ėmile Durkheim and Marcel Mauss on magic, religion, and primitive forms of classification, the French school of sociology can be credited with the first book devoted specifically to the study of ritual, central to the consolidation of sociology and anthropology within the academic panorama. Rites of Passage, by Arnold van Gennep (2011), published in 1909, gained status as a classic. Van Gennep conceived of ritual as an autonomous universe of investigation. Within a context still contaminated by the evolutionist paradigm, van Gennep put forth a relativistic perspective, stressed the dynamic nature of ritual phenomena, and incorporated a vast set of ethnographic data into his analysis.

According to van Gennep, ritual was endowed with three invariant stages: the preliminary (separation), liminality (transition), and post-liminal (incorporation). In emphasizing the unfolding of these stages, he demonstrated the construction of an extraordinary state in which the norms and 
rules of social life became suspended, and during which specific transformative symbolic processes took place, that is, processes capable of altering the identities and social status of people or groups.

Another French precursor, albeit less well-known, specifically used the metaphor of theater to think about ritual processes. Beginning in the 1930s. Michel Leiris studied ceremonies of trance possession among Ethiopian Gondar people, systematizing them in his book, La possession et ses aspects théâtraux chez les Éthiopiens de Gondar. In this work (Leiris, 1958) zar entities are compared to theatrical characters, composing a list of personalities that a medium has at his disposal, dressed as occasions demand. Refusing to consider trance possession a psychopathological phenomenon or mere artifice of interest, Leiris resorted to the concept of theater as a mediator for the European public. He characterized as lived rituals the type of trance possession that he considered as authentic, that is, of marked magical-religious nature. In contrast, he defined those based on spectacularization or endowed with artificiality or pretense as represented ritual, meant to garner material or moral benefits for the medium. From this prism, the experiences of trance possession lay halfway between life and theater (Leiris, 1958; Brumana, 2003), emerging as a fusion of elements from cultural tradition, intersubjective experience, therapeutic, reflexive and leisure aspects.

In a recent publication, Maria Laura Viveiros de Castro Cavalcanti rendered little-known texts by English social anthropologists, such as Evans Pritchard, Meyer Fortes, Hilda Kuper, and Monica Wilson, originally published between 1920s and 1940s, available in the Portuguese language. In these writings, the authors, precursors in the study of festivity, rituals, dra$\mathrm{ma}$ and performances, discussed social phenomena and experiences "[...] elaborated and experienced through dance, music, songs, festivity, corporeality, affect and the use of human senses" (Cavalcanti, 2014, p. 15).

Despite these instigating and pioneering studies, the social sciences were slow in developing an approach to specifically theatrical phenomena, emerging only later through the works of sociologists such as George Gurvitch, Jean Duvignaud, and Erving Goffman (Carlson, 2010; 2011). In the anthropological field, Victor Turner is the scholar who is mostly responsible for connecting ritual, theater, and performance, as is examined in greater detail below. 


\section{Between Social Dramas and Performances}

In the fieldwork he carried out during the first half of the 1950s with the Ndembu of Central Africa, Turner followed in the steps of his mentor Max Gluckman in arguing that rituals "[...] dramatize social tensions in all their ambivalence" (Cavalcanti, 2007, p. 129). Nonetheless, unlike Gluckman and other British structural-functionalist authors, Turner accentuated the procedural and creative dimensions of ritual phenomena. Social drama was the concept at the heart of this new analytical perspective, introduced in Turner's 1957 work, Schism and Continuity in an African Village. It allowed an "[...] explicit comparison of the temporal structure of certain types of social processes with that of dramas on the stage, with their acts and scenes, each with its peculiar qualities, and all cumulating towards a climax" (Turner, 1957, p. 34).

Social drama, understood as the primary unit of description and analysis of social processes, reveals "[...] the unfolding of actions within a clear temporal and spatial frame" (Cavalcanti, 2007, p. 136), as well as "[...] social characters/actors' subjective, affective, and cognitive experiences of structural principles" (Cavalcanti, 2007, p. 135). In addition to revealing the foci of tension within the social structure, these processes provide "[...] a place for potential reflection, analysis and self-analysis, as well as for conceptual and inner transformation of the Ndembu person in his or her relationships" (Cavalcanti, 2007, p. 135).

The phases of van Gennep's rites of passage were reformulated within Turner's concept of social drama, now comprising four stages. The preliminary moment unfolds into stages of (i) the breach of regular social relations which, by gaining public dimensions, may lead to a period of (ii) crisis, along with the expansion of conflict. Liminality is essentially present in the stage of (iii) redressive action (compensatory or regenerative), varied in nature which, as a response to the impasse, leads to (iv) conflict resolution and group reintegration. or its inevitable rupture (Turner, 1957; 1982). The time-space structure that unfolds reveals a dramatic narrative articulating past and the present, and contains "[...] the origin of a future or a necessary destiny" (Cavalcanti, 2007, p. 135) $)^{5}$. Although overdetermined by the anticipated end fate (Cavalcanti, 2013) associated with impending conflict, 
this framework was of great value for the analysis of different phenomena of social life, including rituals, political phenomena, processions, revolutions, counter-cultural, and artistic movements (Turner, 2008; 2013; Peirano, 2001).

The notion of liminality in Victor Turner is not restricted to usual disorderly behavior, ritually framed, as compensation for an overdose of social rules. Along with the concept of communitas ${ }^{6}$ developed in his 1969 work, The Ritual Process, Turner always emphasized the creative, innovative, and polysemous dimension of liminality, associated with symbols in action (Cavalcanti, 2012; 2013). As Cavalcanti points out, in Turner's conception:

[...] the ritual is, at one and the same time, a characteristic socio-cultural and situational context. In this environment, impregnated with beliefs and values, symbols exercise their full effectiveness as articulators of perceptions and classifications, becoming factors capable of impelling and organizing human action and experience and revealing the underlying cultural themes (Cavalcanti, 2012, p. 119).

Milton Singer's (1972) notion of cultural performance was developed in dialogue with Turner's concept of social drama. Singer also conceived of cultural performances as elementary units of culture and specific forms of observation. Furthermore, his category integrated western and eastern expressions, ritual and artistic phenomena at its core. Plays, dramatizations, dances, concerts, readings, prayers, recitations, rites, ceremonies, and festivals (Singer, 1972) were all understood as performances, characterized by temporal duration - actions carried out according to an organized program, the existence of performers, audience and places and occasions for their consummation (Singer, 1972). Without neglecting to consider specialists, as well as interpretative and evaluative clashes, Singer demonstrated the privileged place these expressions could take on, in analyses of tensions and continuities between the urban and the rural, the traditional and the modern, both in terms of communicative dimensions and the scope of social change.

The influence of Dell Hymes, considered the founder of speech and communication ethnography ${ }^{7}$, is present in Singer. In his desire to understand the place of language in social life, Hymes was an important precursor to the study of speech acts and events. He refused to limit himself only to 
revealing cases of the grammatical norm, insisting on the need for direct (ethnographic) investigation of language in specific cultural moments and contexts.

In Breakthrough into performance, Hymes (1977) presents a definition of performance that encompasses the dimensions of interpretation, narrative exposition, repetition, and acceptance, to highlight the importance of the audience within communicative phenomenon. In his view, performance is an action in which one or more people assume responsibility before the audience and tradition. It necessarily involves an act of demarcation $\left(\right.$ frame $^{8}$, an element which differentiates performance from conduct, that is, from regular behavior ruled by social and cultural norms. This definition exerted great influence not only on the studies of folklore, ethno-poetics, linguistics, and anthropology but also on later studies of performance.

Marvin Carlson (2011) remarks on the 1970s confluence of the works of experimental theatrologist Richard Schechner and those of Victor Turner, Edith Turner, Erving Goffman, Konrad Lorenz, Jane van LawickGoodall, and Ray Birdwhistell. A fertile interdisciplinary, academic and artistic exchange took place during this period, resulting in events, publications, and spectacles and constituting a veritable inaugural moment of Performance Studies.

In the influential volume Performance Theory, published in 1988, Schechner had already sought closeness to the field of anthropology, attempting to bring a broad constellation of events together under the performance label, including theater, ritual, shamanism, games, the performance of everyday roles, ceremonies, sports, and entertainment. For the author, performance is restored behavior or twice-behaved behaviors, which means, something learned that, on one hand, reveals its internalization according to specific rules and standards and, on the other hand, that which separates the action itself from its specific socio-cultural references (Schechner, 2003).

Both Carlson (2011) and Cavalcanti (2013) accentuate a common dissatisfaction of this set of authors belonging to the context of the 1970s, moving them closer to the post-modern turn in anthropology, a movement that found characteristic expression in Clifford and Marcus' (1986) key work. While the publications From ritual to theatre (1982), and the post- 
humous volumes The anthropology of experience and The anthropology of performance, from 1986 and 1987, manifest their annoyance with academic rationalization and authoritarianism, they also mark a thematic turning point regarding Western performance, yet gesture toward decontextualized theorizations ${ }^{9}$, universalizing in character.

Encouraged by his cooperation with Schechner, Turner assumes the former's proposal of conceiving feedback between social drama and cultural performances, representing this connection through the image of a horizontal number eight (Turner, 1982) which is the sign for infinity. This schema, admittedly a balancing act, holds that the public dimension of social drama affects the implicit social process which tends to generate a variety of manifest cultural performances. These, in turn, affect the implicit rhetorical structure of society, leaving room for new social dramas.

Turner, however, could not conceive of African ritual manifestations as endowed with the same subversive character that he identified in other genres of Western societies. This led him to resort to an orchestration of concepts such as leisure, play, flow, and, especially, to the differentiation, of evaluative character and ethnocentric foundation, in referring to the liminal phenomena of traditional societies that are present in modern ones (Turner, 1982). It is only in the latter, labeled liminoid by him, that qualities of freedom, individuality, free will, plurality, fragmentation, experimentalism, reflexivity and a greater propensity to the subversion of the status quo were to be found (Turner, 1982).

The analytical framework developed by Turner, Schechner, and several other collaborators led to productive and interdisciplinary analyses consolidating a fertile path for the anthropology of performance ${ }^{10}$. Some appropriations of these reference texts, however, promote a mechanical application of the phases of social dramas in a given ethnographic context, disregarding the relationship between symbolic action and its context. As we have stated on other occasions (Krüger, 2008a; 2008b; 2017), Turner's excessive attention to the restorative process may have been responsible for limiting the analysis of cultural performances in the phase of restorative action, with its public dimensions, favoring a type of decontextualized reflections that he had never allowed in his studies of Ndembu rituals ${ }^{11}$. 
Based on vague and esoteric concepts of rhetorical structure, implicit social process, unconscious and manifest dimensions of phenomena, his proposal silences exactly that which analysis should be able to uncover. Here, Turner is far removed from his ethnographic approach to ritual studies. Although the underlying temporal diachrony remains, his model reifies the autonomy of aesthetic phenomena in the face of the events of social life. Paradoxically, we here face an essential dichotomy between lived theater and represented theater which not even Leiris dared to postulate. Intending to sustain symbolic, expressive, and universal sensorial elements ${ }^{12}$, Turner seems to lose sight of both the contextual dimension of the artistic phenomenon and its unique agency and ethnographic sense (Turner, 1988; 2015; Turner; Bruner, 1986). The feedback between social conflicts and the dramas represented on stage also alludes to a mere mirroring that eclipses the conflictive dimensions of tradition, of innovation processes and the evaluation of cultural performances, as well as symbolic disputes, rivalries or affinities between performers, audiences, critics, and institutions. Seeking to incorporate these issues into current analyses is a fruitful path for the anthropology of theater that we propose here.

\section{Is the Drama Over?}

Peter Szondi would certainly raise objections to Victor Turner's appropriation of the notion of drama. An essential reference on the theme, Szondi's concept of drama was historical and dialectical. Born in the Renaissance, the central characteristic of this artistic genre lies in intersubjective action expressed through dialogue, the "[...] only component of dramatic texture" (Szondi, 2001, p. 30). This excludes well-known expressions that allow other narrative structures, such as Greek or Shakespearean theater, from the category of drama.

Drama thus characterized is defined by (i) its absolute character, that is, its break with everything external to it, which in turn implies (ii) the absence of the playwright, who although responsible from configuring the dramatic situation, is now separated from it -actions and dialogues are seen as coming from on stage subjectivities. There is also (iii) total separation and passivity on the part of the spectator, who merely watches what unfolds on stage, although dramatic illusion often generates empathy and involve- 
ment and (iv) perfect theatrical illusionism, both in terms of space (traditionally the Italian stage, or black box) and interpretation, with the actor and his role in perfect connection. Action (v) must be seen as original, unique - drama represents nothing but itself; it is (vi) always occurring in the present; the progression of the drama is a temporal sequence of absolute presents and involves (vii) unity of place (Szondi, 2001).

In addition to providing a characterization of dramatic form, Szondi also highlighted its late 19th century crisis, when action, present time, and intersubjectivity were unsettled in plays by Ibsen, Tchekov, Strindberg, Maeterlink, Hauptmann, among others. The following century would also witness several metamorphoses (which Szondi understands as attempts to resolve the crisis of drama), undertaken by referential playwrights like Brecht, Pirandello, or O'Neill. Articulations of memory and immersion in the intrasubjective universe, rather than intersubjective present, decreased action and emphasis on the dreamlike or utopian world, and even the substitution of illusionism by the epic form, shaking the foundations of the canonical dramaturgical model.

New and significant dramatic changes were registered at the end of the 20th century. Contemporary authors show a marked influence of the Brechtian aesthetic (although without similar ideological commitment) and the authors of the Theatre of the Absurd ${ }^{13}$ introduce important singularities into their writing: little or no allusion to the historical context, scant reference to time and space, great interest in the use of non-dramatic texts, fragmentation of the narrative and robust use of deconstructed or weakened characters (Ryngaert, 2013; Sarrazac, 2017).

Among the aforementioned changes to the conventions of modern drama, perhaps the most evident is the manipulation of the theatrical dialogue resulting in disconnection of speech and action, a tendency to "[...] undermine the situation and thus push back the limits of the "dramatic" (Ryngaert, 2013, p. 138). This is what Jean-Pierre Ryngaert (2013, p. 137) denominates "[...] the theater of conversation [...]", in which "[...] nothing or almost nothing is 'acted', in which the only action is speech". Therefore, verbal exchanges, the qualities of their emission and profusion prevail over situations, even though the information emanating from these words is "[...] anodyne, light, superficial and without any direct obligatory relation 
to the situation" (Ryngaert, 2013, p. 137). Abundant, excessive, redundant, or, conversely, laconic, rare, implicit, almost anemic words are common. It is not known with certainty who emits these words, nor to whom they are addressed. The random enchainment of the replicas, the discursive fragmentation, the entanglement of the themes as well as the flows, hesitations, interruptions, or movements of consciousness of the dialogues are taken to the limit. Whether in staging or reading the text, contemporary dramaturgy turns the extralinguistic apparatus underlying discourse into the main bearer of meaning to the detriment of the content of the discourse or the unfolding of the plot (Ryngaert, 2013).

A "[...] staging of speech [...]" like this releases the scene "[...] from the weight of the characters" (Ryngaert, 2013, p. 151) turning them from something important into something of lesser importance. That is why "[...] the open character is contemporaneous to the end of the empire of the fable" (Abirached apud Sarrazac, 2006, p. 359), or, more precisely: "[...] the crisis of the character is but one of the effects - unquestionably the most spectacular and the most directly perceptible - of a crisis of mimesis" (Sarrazac, 2006, p. 355). The French theorist Jean-Pierre Sarrazac argues that modern and contemporary dramaturgy "[...] has done nothing more than reconstruct the movements of this 'ghost without substance', reconstituting its spectrum" (Sarrazac, 2006, p. 363, our translation).

This abstract, dead, false subject, an incurably lost self expresses the suppression of subjective enunciation from the plays of Strindberg, Pirandello, and Beckett. In contemporary dramaturgy, this process reaches an acute degree, so that depersonalization became impersonalization of the character (Sarrazac, 2006). This is a far cry from the recognition of an active hero who undergoes processes of transformation of his status over the course of the dramatic events. Characters conceived by authors such as Nathalie Serraute, Michel Vinaver, Philippe Minyana, Noële Renaude, and Jean-Luc Lagarce (dramaturgical influences of the companhia brasileira de teatro), tend to be apparitions or almost identifiable subjects that profess incoherent texts.

Working with the conception of mimesis further removed from the idea of imitation or representation, Sarrazac understands it as an act of rendering presence. Thus, the modern character can be seen as the presence of the 
absent or absence made present. Instead of a mimetic procedure capable of evidencing veracity and coherence, what we perceive, through the performance of these characters, is the explicitness of the relationship between the interpreter and what he or she may become on stage, an application of ambiguity and multiplicity on-scene.

In the context of the last quarter of the 20th century, representation no longer constitutes a translation of the text for its staging, but rather is seen through the polysemic notion of writing for theater. As Bernard Dort (apud Féral, 2015, p. 11) has well summarized: "Since then there has been no fundamental agreement between spectators and theater people on the style and meaning of these plays. The balance between audience and stage, between the demands of the former and the order of the latter is no longer taken as a postulate". More than a clash between the forces of the text and staging, the most recent scenario reveals continuous displacement of theatrical signs, unheard of and contradictory processes of combination, in confrontation under the spectator's gaze. Given such a configuration, the director loses his or her sovereignty without returning to the omnipotence of the text: "Currently, through the progressive emancipation of its different components, representation opens itself to the activation of the spectator and reconnects with what may be the vocation of the theater: not of staging a text or organizing a play, but providing critique of processes of meaningmaking" (Dort, 2013, p. 55). This is why, in Dort's view, theatricality is fundamentally the questioning of meaning.

In this new configuration of emancipated representation there is no pretense of orderly organic unity: text, space, interpretation, and the other staged elements gain independence within the play and aim at polyphony in meaning-making, interpretive openness, becoming a kind of dispute around the meaning of the play in the spectator is judge (Dort, 2013).

A similar process occurred with dramaturgy. Still predominantly seen as synonym for theatrical text, whether referring to the production of a particular author, period, or theme, the term also bears other meanings (Torres Neto, 2016; Pais, 2016; Fernandes, 2013). Even the most common use, as technique of drama composition, which implies the bourgeois notion of pièce bien faite, based on characters, conflicts, dramatic action, crises, intrigues, entanglements and outcomes, meant to generate suspense and lead 
to an illusionist narrative (Torres Neto, 2016) has been losing strength, yielding to today's "[...] mode of structuring and relationships of meaning within the play" (Pais, 2016, p. 25).

\section{Per-For-What?}

The long process of mimesis deconstruction that unfolds in the rupture of dramatic conventions related to action, dialogue and the conception of characters that we review above reveals the significant influence of the language of performance. While it is difficult or even inadvisable to attempt a definition of the concept, due to its plurality and unavoidably disputed nature (Carlson, 2010; Féral, 2015), much can be said about what the notion of performance negates. From the initial contributions of early $20^{\text {th }}$ century European modernist vanguards to the explosive impulse of the 1960s, with its body art and happenings, opposition to dramatic theater could not be clearer. All these artistic expressions reject theaters and conventional exhibition spaces, tending to make use of public space (predominantly urban) or places seen as an alternative, valuing openness to the unexpected, to chance and spontaneity (as opposed to the more disciplined and controlled creation through rehearsals) and also seeking diverse forms of approximation between (or even indistinctness of) stage and audience, actors and spectators.

Hybridity, iconoclasm, and non-conformity are also common features of happenings and performance art, which as desire for living expression that refuses the separation between art and life, openly confronts the conception of the work of art as a finished object and as a commodity. This becomes evident in notions such as representational rupture, accentuation of the present moment, ritual dimension, uniqueness or complicity, robustly employed by the most diverse studies of the theme. From this questioning of the dramatic comes the transformation of the actor into a performer, the collapse of representation replaced by mere action, the increased importance of the body (and later of the image) in relation to earlier previous sacralization of the word and the dramatic text, the breaking of the fourth wall that reveals either the desire for interactivity or the rupture of the habitual passivity of the spectators sitting in front of the stage. 
The 1970s bear witness to the preeminence of performance over the happenings of the previous decade. This transition implies a decrease in collective, ritual, tendencies, and in the importance of the body and chance (associated with counterculture and the hippie movement), towards the expansion of conceptual characteristics, aesthetic concerns, and the use of technological, imagery, and media devices. In the words of Renato Cohen (2002, p. 100) " [...] the work becomes much more individualized. It is the expression of an artist who verticalizes her entire process, according to her own interpretation of the world, and from then on creates text (in the sense of sign), script and mode of acting". This actor-stager who mobilizes material from her daily life, explores her autobiography rarely using a character (self as context), and emphasizes bodily activities in space and time, constitutes one of the main trends of this language. The other is the "[...] tradition of more elaborate pieces no longer based on the individual artist's body or psyche, but rather on the demonstration of non-literary, visual and oral images, always involving spectacle, technology and mixed media" (Carlson, 2010, p. 120).

Although resistance to the traditional theater has been essential for the purposes of performance, its historical development reveals a recrudescence of opposition to the theater as well as a return to discursive language and greater aesthetic elaboration. While strictly associated with the visual arts in "[...] its origin, its history, its manifestations, its places, its artists, its objectives, its conception of art, its relationship with the public" (Féral, 2015, p. 122), performance ended up benefiting the theater widely: its virulence with regard to the basis of dramatic art made the contemporary theatrical experience expand over time. Theater became performative (Féral, 2015).

Starting from the well-known definition of performance by theorist Richard Schechner, that the nature of performative performance involves a certain behavior (mode of being), an action and a manifestation of the action, and connecting these assumptions to Derrida's thought, Josette Féral (2015, p. 122) understands performative works as composed along two axes. There is "[...] on the one hand, its nature as describer of facts. On the other, actions which the actor there performs. Performance takes place in the real and focuses on that very reality in which it is inscribed, deconstructing it, playing with the codes and capabilities of the spectator". In this 
playing with signs, the instability and fluidity resulting from the artistic phenomenon undoes univocal meaning and impels the spectator to constantly search for meanings and senses, because the performer "[...] installs ambiguity of meanings, displacement of codes, slips of meaning. It is, therefore, a matter of deconstructing reality, signs, meanings and language" (Féral, 2015, p. 122). Thus, there is great similarity between this performative theatre, recent trends in staging and recent articulations of contemporary dramaturgy.

\section{The companbia brasileira de teatro and the PROJETO bRASIL}

Founded in 2000, in the city of Curitiba, the companhia brasileira de teatro reveals a consistent artistic trajectory, having done dozens of shows, received several awards ${ }^{14}$, and garnering significance relevance on the national theatrical scene. Contrary to what the word brasileira may lead one to believe, the group has not distinguished itself by the promotion of artistic form or content that is characteristically national. Throughout its trajectory, the plays staged have been mostly previously untranslated plays by contemporary foreign playwrights such as Philippe Minyana, Jean-Luc Lagarce, Noëlle Renaude, Joel Pommerat, Ivan Viripaev, and Hanoch Levin. These texts are characterized as belonging to theater of conversation, as well as by their infra-dramatic configuration, their exploration of the intimate, interpersonal, and daily universe of non-characters. Thus, we can assert that group has built its trajectory in affinity with European (especially French) dramaturgy, accompanied by the development of a unique intellectual and linguistic capital, and through the creation and maintenance of a vast network of personal and professional relationships in the publishing and theater world (Krüger, 2017).

During the ethnographic research I carried out with the company from the end of 2013 to August 2016, I took part in closed rehearsals, open rehearsals, lectures and workshops and was able to analyze videos of plays, photos, images, dramatic texts, reviews, and company archives. Over this research process, the type of theater desired by the group became clear: it is meant to promote encounter with the other. The rupture of representation, the affirmation of the present, the explicitness of theatricality, and enuncia- 
tions addressed directly to the audience were recurrent and characteristic processes of their creations.

As we will see, PROJETO bRASIL represented a turning point in the repertoire of the companhia brasileira de teatro. Since its creation, the aim of its mise-en-scène has not exactly been to provide a theatrical interpretation of contemporary Brazil. According to director Marcio Abreu: "We do not seek to make a portrait of the country. Nor is it a play about Brazil. It is, in fact, a play that originates from Brazil. And this conscience guided the entire work. Creating something 'starting from' rather than 'about'" (Abreu apud Brasil, 2016).

The creative work of putting the show together (which was sponsored by the Petrobras company ) was organized in four stages: (i) a process of academic research that included bibliographic analysis, organization of seminars with invited professors and researchers ${ }^{15}$; (ii) an ethnographicallyinspired expedition through cities in all regions of the country, which combined the presentation of pieces from the company's repertoire with workshops and meetings with artists and local residents ${ }^{16}$; (iii) an intense rehearsal period based on improvisations and collective creation and iv) a show season. Through this articulation of artistic research initiatives, the group expected to find inspiration for a de-dramatized micro-fable (similarly to its 2010 play, Vida) that would serve as the project's guiding thread.

Throughout the rehearsals, such expectations came undone and the group decided to abandon theater of conversation and deliberately embrace performative theater. Eleonora Fabião's advice, which was concretized through a workshop, became indispensable for the play's definition. PROJETO bRASIL thus became a "[...] dramaturgical composition articulated in sixteen verbal and non-verbal speeches of a performative nature" (Abreu, 2016, p. 51). It can be said that in its creative process, the group experienced the type of crisis of anthropological authority praised by postmodern anthropology (Clifford, Marcus, 1986; Caldeira, 1988). Even with the bibliographic and academic support mobilized and with the experience of field research carried out in different cities throughout the country, no Brazilianness that was brought to the stage seemed adequate or sufficient for the group. Therefore, rather than aligning multiple discourses about the coun- 
try in an authorial dramaturgy, as they had initially desired, the company turned the discursive act itself into the central theme of the show.

Several scenes in the play are built on the action of taking the floor, of speaking to an audience, or even on the impossibility, illegitimacy, or inconsistency of this speech. This theatrical metadiscourse is accompanied, from the beginning of the play, by the explicitation of the conviviality, the sharing of the present moment between actors and spectators:

[...] I would like to thank you for the chance I received to be here before you, it is an absolutely meaningless moment, to be put in this situation, finally, having to say to you, before you, for you, what comes after the end. So I have a few words to say, they are few, but I want to share them because without you I would do the same, but I want to do this before you, with you for you [...] everything I have to say has already been said, has already been written and lived by someone much more moved than I, with a voice more powerful than mine, this voice must be forgotten by all of you, just as I have forgotten it, there is no voice saying anything to you here (Abreu, 2016, p. 54-55, my emphasis).

The above passage alerts spectators to the ambiguity and contradiction of discourse, forewarning an ambivalent treatment of the country, which would be the underlying tone of the spectacle. After a long and frustrating search for national examples, two pronouncements made by foreign political personalities were incorporated into the play, constituting the most substantial part of its dramatic text. In a speech made to the French parliament in April 2013, Cristiane Taubirá, the French Minister of Justice at the time, defended the recognition of families formed by same-sex couples, as well as their right to adopt children. Jose Mujica delivered a speech at the UN in September 2013 in which he criticized contemporary capitalism, arms build-up, and neoliberal politics, based on his experience in life and as president of Uruguay. There was no reference to the authors of the texts during the play (except for the use of Spanish onstage and mention made to the two politicians in the program). Rather, the intention was to effectively take the speech from its speakers, switching audience and enunciation context, a fact that also explains the adoption of full-length speeches.

It is no coincidence that the scenes that deliberately use these speeches are interspersed with others that play with word combinations in a Dadaist manner, as in the one I transcribe below: 
Hey, Neide Caveirãol

Auntie Mirian/

Mr. Antonio polacol

Hi, Real Misery / You friends, get out /

104 dead Indians fell on the sidewalk/

Hey, Brazilian/

You were stuck in the invaded continentl

Dead boss, poor guy/

Crossings, tears, then

Between fiction/

Reality/

Bloody blood rose sickeningly/

The copsl

Arrested fine people pointless stuff pressure/

Fortheloveofgod (woe, woe, woe, woe)/

Lady violence (ô yes, ô yes)/

Fragile child (si si si)/

Noel knew/

Tiziu well-hung fucked alemãol

Deeply/

Inside Carlos lost to Grandma Ceição/

Swaying costume jewelry witchcraft/

D. Eva dancing a quick dance all of a sudden she'll be she'll be/

Mur-dered/

Shoot I faced differencel

I am much better brazill

Cocaine frame $100 \%$ pure clarity there is hunger yes/

[...] (Abreu, 2016, p. 64, grifos meus). 


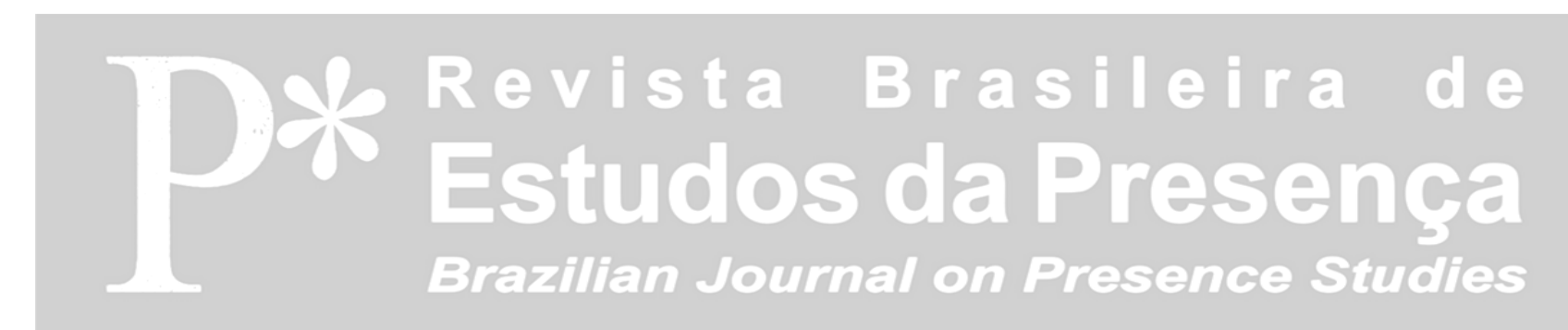

E-ISSN 2237-2660

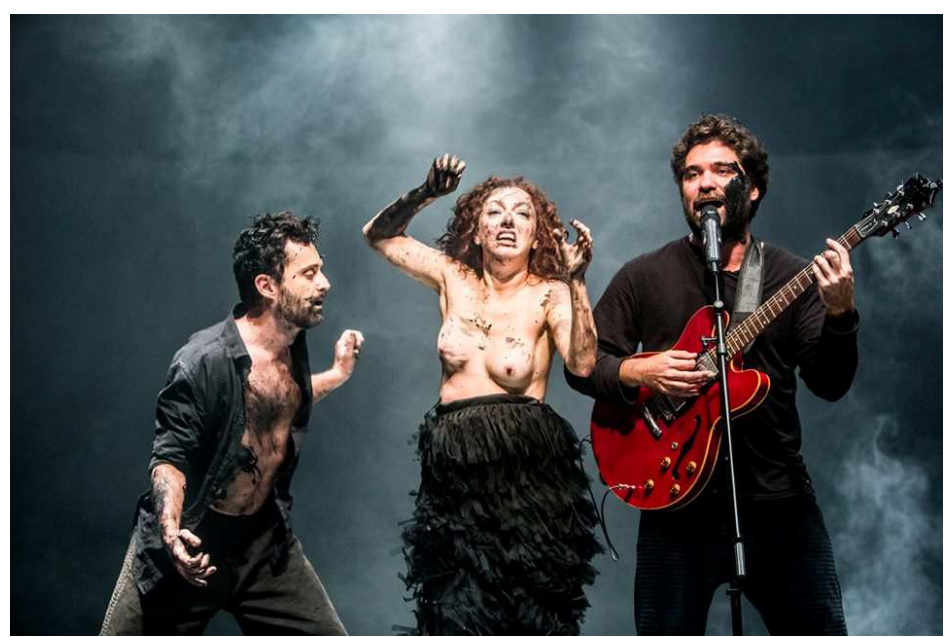

Figure 1 - Rodrigo Bolzan, Giovana Soar, and Felipe Storino on the scene of Discourse 6, part of the play PROJETO bRASIL. Photo: Elisa Mendes.

Source: Facebook page of companhia brasileira de teatro.

The text above, a collective creation later put to music by Felipe Storino, alludes to people, situations, localities, conflicts, or regional expressions experienced by the company over the course of its field research. Following the performance of live music, Giovana Soar and Rodrigo Bolzan perform a gaga dance, in evident parody of well-known expressions of the Brazilian pop music industry, while the fourth actress of the play, Nadja Naira, merely observes the scene, on stage, an expression of disapproval on her face (Figure 1).

Another high point of the mise-en-scène is a solo, non-verbal scene with actress Giovana Soar. Soar, placed center stage, facing the audience, begins a series of gestures, expressions, and unintelligible sounds, using movements of arms, hands and facial expression. The strange choreography ends and is repeated, this time in synchrony with Caetano Veloso's song, Um Indio, in the voice of Gal Costa. With the correspondence of movement and music, the audience is able to perceive that gestures refer to the translation of the lyrics into the Brazilian sign language (LIBRAS). In this way, the scene connects two conditions of alterity: the deaf population and indigenous groups in Brazil, placing the public (mostly white and hearing) in the condition of other. The emotional charge is enhanced, in the repetition of the scene, by a visual strategy: the actress wets her hands with red gouache ink - evoking the red pigments of the urucum tree, and to blood, in evident allusion to the historical genocide of the Brazilian indigenous population and its persisting impunity (Figure 2). 

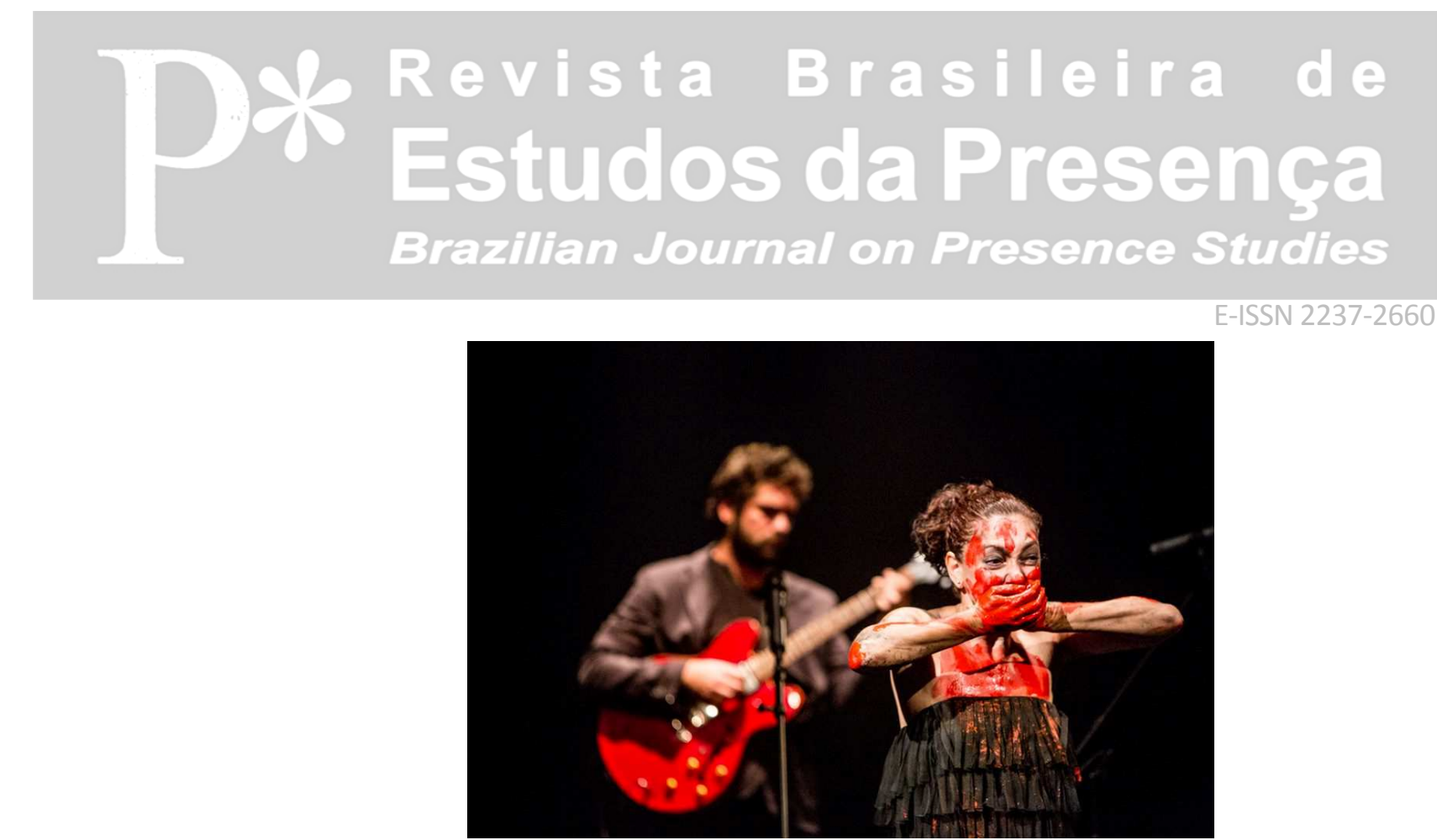

Figure 2 - Giovana Soar performing Um Índio de Caetano Veloso in LIBRAS in Discourse 11, part of the show PROJETO bRASIL. Behind her and out of focus is Felipe Storino. Photo: Elisa Mendes.

Source: Facebook page of companhia brasileira de teatro.

These excerpts from the play are enough to demonstrate the particular association that the theater company makes of performative theater and contemporary dramaturgy. PROJETO bRASIL is characterized by the absence of a cohesive narrative, of any dramatic conflict or of characters (the actors appear as collective enunciations that deliver fragmented speeches with a high level of abstraction and ambiguity), by the ambiguity and reflexivity largely played out through the use of metadiscourse and by the mode of allusion to symbols considered as national. As I argued on another occasion:

Brazil was not be approached, scrutinized, analyzed, or narrated directly by the spectacle, but continued onstage as an absence, as a non-totality, as an unrepresentable concept. Furthermore, this creative strategy [...] reveals an interesting parallel with contemporary dramaturgy, as like bourgeois drama, one can say that Brazil appears on stage only as 'shadow', as an absent reference, suppressed, weakened, resignified. To this is added the company's proposal of avoiding national stereotypes, or, more correctly, to destabilize them, dislocate them, subvert them, complexify them (Krüger, 2019, p. 55).

Theorist and critic Luciana Romagnolli (2016) argued, in a text included in the book on the play, that "[...] [the] conflict taken on by this dramaturgy - and by this country, and by this world - is, at last, between love and violence". Perhaps this is the central argumentative axis of PROJETO bRASIL: ambivalences linking love/identification and violence/denial. The group does not dare to enunciate a Brazil, but points to a non-country, either in terms of what comes from abroad and what is wanted 
here, or in its eternal becoming, its quality of project, always inconclusive, still miniscule, as the letter $b$ in the title of the show.

\section{For an Anthropology of Theatre}

Festivity, dance, love, friendship, Brazilian popular music, poverty, diversity, inequality, otherness, physical disability, prejudice, indigenous groups, rape, violence, slaughter, mourning, impeachment, corruption, patriarchalism, gender, same-sex marriage, adoption, family, environmental crisis, global capitalism, neoliberalism, sustainability, end of the world, Anthropocene, democracy and citizenship are some of the themes alluded to on stage. This enumeration demonstrates the impossibility of identifying a central dramatic axis or even the play's recognition of any climax, conflict resolution, or outcome.

Pointing out the critical, subversive, and political character of theater, or its liminal quality would be banal. Similarly obvious is the notion that the mise-en-scène was created based on real experiences, transformed into performances which in turn, has impact on the social world. More fruitful is to consider, as we did (albeit briefly), through ethnographic work and participant observation, some of the characteristics and driving elements of the company's artistic creation, and the interesting tension between the performative (Féral, 2015) and conversation (Ryngaert, 2013). I seek to treat notions such as theater, drama, performance, and contemporary dramaturgy as realms to be researched rather than as pacified concepts, and to point to struggles over meanings, expectations, desires, and critique of artistic creation.

As anthropological knowledge "[...] consists not in propositions about the world but in the skills of perception and capacities of judgment that develop in the course of direct, practical, and sensuous engagements with our surroundings" (Ingold, 2014, p. 387) it tends to be produced with others rather than merely speak about them (Ingold, 2019). This was the path we took with the companhia brasileira de teatro and the creative process of putting together PROJETO bRASIL.

This path led to my recognition, to the imperative desire of dealing with the troubled national context of the years 2014 to 2016, a kind of cooptation of discourse was added, a crisis of artistic authority similar to the 
crisis of authority that affected anthropology in the 1980s and 1990s. I have demonstrated how the use of performative theater, meta-discursive and dedramatization strategies made it possible to shift the viewpoint of spectators, enabling those on stage and those in the audience to change places. The way scenes were structured (dramaturgy in the broad sense) demanded from spectators not only interpretative efforts regarding plot, but also a continuous questioning and shifting through the frames of the scenes, as well as sharp reflections on meanings and sensations.

More than a fertile ground of perennial social dramas, Brazil, its images, its discourses, and its contradictions move on as a process of becoming, a project, desubstantialized, onstage and offstage. PROJETO bRASIL continues to resonate.

\section{Notes}

1 This research field has been spread throughout the globe mainly by Jean Marie Pradier. For more on the subject, see Pradier (1998) and Bião (2011).

2 Here, the expression refers to the works of Eugênio Barba, a scholar who does not concern himself with presenting a social or cultural anthropology approach to the world of theatre (Krüger, 2008a).

3 A more complete discussion of the state of the art in the areas of anthropology of theater and ethnocenology is not the goal of the present paper. On the other hand, a closer examination of the international milestones of anthropology of performance will be developed below.

4 Anthropological research on theater in Brazil (Araújo, 2009; Coelho, 1989; Castro, 2012; Mariz, 2007; Toledo, 2007; Krüger, 2017) is rare and emerges largely from postgraduate researches that enjoy limited circulation. Predominantly ethnographic studies of actors, they advance reflections on the notion of the person, the body, projects, lifestyle, and world-view, as well as analyses of learning and application of theater technique. Although this type of literature is an important source of inspiration, with few exceptions, it does not focus on the universe of contemporary theater and theater troupes, nor is it concerned with linking artistic creation to its immediate context.

5 The author maintained that a significant part of the confrontational propensity among the Ndembu was associated with the contrasting principles of matri- 
lineality (descent through the maternal line) and virilocality (a rule that obliges women to reside in their husbands' village).

6 A fundamental characteristic of these manifestations of liminality or antistructure is the temporary suspension of regular normative standards regarding constraints, coercion, roles, and duties; this tends to generate a cognitive, affective, volitional, and creative liberation of individuals, prone to the creation of more inclusive, spontaneous, free forms of great reciprocity among participants, which Turner called communitas (Turner, 1982; 2008; 2013). The concept gained significant relevance and has been explored within numerous configurations of anthropological literature.

7 Dell Hymes, along with Denis Tedlock, Richard Bauman, Charles Briggs, and the language philosopher John Austin (1962) constitute the second current of great influence for the anthropology of performance. See Carlson (2010), Bauman (2014), and Langdon (2007).

8 Equally valuable contributions to this concept are the formulations of Gregory Bateson and Erving Goffman. The establishment of a frame promotes demarcation and acts in the process of separation-inclusion of social phenomena, organizing perception and, consequently, becoming fundamental to the processes of perception, knowledge, and metacognition (Goffman, 2012).

9 Although he recognizes differences in genres and theatrical styles, Turner (1982, p. 12) opts for an increasingly universal theorization: in his view, theater "[...] owes its specific genesis to the third phase of social drama, a phase which is essentially an attempt to ascribe meaning to 'social dramatic' events[...]", which is the reason that we find " in theatre something of the investigative, judgmental, and even punitive character of law-in-action, and something of the sacred, mythic, numinous, even 'supernatural' character of religious action".

10 Some names of global importance are Dwight Conquergood, Diana Taylor, Barbara Kirshenblaty-Giblett, Marvin Carlson, Philip Auslander, among others. In Brazil the anthropology of performance is a fertile area, as the publications of Ferreira, Müller, (2010); Dawsey, Müller, Hikiji, Monteiro (2013); Raposo, Cardoso, Dawsey, Fradique (2013) attest. Also see Silva (2005), Peirano's provocative article (2006), and the recent state of the art by Hartmann and Langdon (2020). 
11 On this point, Richard Schechner (2003) adopts a broader ethnographic scope than Turner, excessively limited to the stage of public performance, including, beyond this stage, proto-performance and its sequels. Proto-performance can encompass training of the most diverse expressive genres of each society, as well as research stages and rehearsals to select and improve the chosen material. Performance is divided into heating up, public performance, and cooling off. The sequel stage includes critical responses, archives, and memories.

12 Turner himself might have been aware of these weaknesses. In From ritual to theatre, the author had already resorted to the creation of comparative symbolo$g y$, a multidisciplinary, intercultural, and universalizing model, as an antidote to possible ethnocentric perils. In The anthropology of experience, Turner reframes the anthropology of performance, placing it within the anthropology of experience.

13 The term refers to "[...] works and attitudes that participate in one way or another in the current of thought that embroils the human being in constant existential anguish, once he finds himself in disharmony with a universe from which unquestionable certainties and basic principles have disappeared" (Vasconcellos, 2009, p. 230-231). Authors such as Samuel Beckett, Arthur Adamov, Jean Genet, Eugéne Ionesco, Harold Pinter, and Fernando Arrabal, although they were not an integrated school or movement, are included in this classification.

14 By 2019, the companhia had accumulated thirty-two awards, fourteen of which were regional (Gralha Azul Trophy; Poty Lazarotto and Mostra da Fundação Cultural de Curitiba) and eighteen of which came from the Rio-São Paulo axis (Questão de Crítica; Cesgranrio; APTR; SHELL; APCA; Bravo! and Revista Contigo) and thereby considered national in scope. The piece entitled PROJETO bRASIL won the prize for best play awarded by the Questão de Crítica (RJ) magazine in 2016, as well as Troféu Gralha Azul in 2015, at which time it also garnered distinctions of best text, best actor, and best actress.

15 Kruger (2017) explains the creative process of the PROJETO bRASIL in detail. The company focused its bibliographical research on reference works by Viveiros de Castro, Débora Danowski, Lilia Schwarcz, Heloísa Starling, Jacques Rancière, and Antônio Negri. The cycle of lectures held at the company's headquarters included professors and researchers dealing with Brazilian literature, Brazilian popular music, popular culture, folklore, and cinema. Ele- 
onora Fabiáo's successful lecture and workshop with the cast of the show should be highlighted.

16 Over the course of its creative process, the companhia brasileira de teatro travelled to the capital cities of Porto Alegre, Rio de Janeiro, Brasília, Salvador, and Manaus.

\section{References}

ABREU, Marcio. PROJETO bRASIL/Maré. Rio de Janeiro: Ed. Cobogó, 2016. ARAÚJO, Carolina Pucu de. Ensaio sobre o ator: a criação de si e o aprendizado da atuação. 2009. Tese (Doutorado em Antropologia Social) - Programa de PósGraduação em Antropologia Social, Museu Nacional, Universidade Federal do Rio de Janeiro, Rio de Janeiro, 2009.

AUSTIN, John. How to do things with words. London: Oxford University Press; Amen House, 1962.

BAUMAN, Richard. Fundamentos da performance. Sociedade e Estado, Brasília, v. 29, n. 3, p. 727-746, set./dez. 2014.

BEEMAN, William O. The Anthropology of Theater and Spectacle. Annual Review of Anthropology, Palo Alto, v. 22, n. 1, 1993.

BIÃO, Armindo Jorge de Carvalho. A Presença do Corpo em Cena nos Estudos da Performance e na Etnocenologia. Revista Brasileira de Estudos da Presença. Porto Alegre, v. 1, n. 2, p. 346-359, jul./dez., 2011.

BRASIL, Ubiratan. Companhia brasileira de teatro viaja pelo País para criar a peça Projeto Brasil. Estado de S. Paulo, São Paulo, 16 jun. 2016. Available at: $<$ https://cultura.estadao.com.br/noticias/teatro-e-danca,companhia-brasileira-deteatro-viaja-pelo-pais-para-criar-a-peca-projeto-brasil,10000057451>. Accessed on: Feb. 13, 2019.

BRUMANA, Fernando Giobellina. Ser otro: Leiris e la posesión. Ilha, Florianópolis, v. 5, n. 1, 2003.

CALDEIRA, Teresa Pires do Rio. A presença do autor e a pós-modernidade na antropologia. Novos Estudos CEBRAP, São Paulo, v. 2, n. 21, jul. 1988.

CARLSON, Marvin. Performance: uma introdução crítica. Belo Horizonte; Ed. UFMG, 2010. 
CARLSON, Marvin. O Entrelaçamento dos Estudos Modernos da Performance e as Correntes Atuais em Antropologia. Revista Brasileira de Estudos da Presença, Porto Alegre, v. 1, n. 1, p. 164-188, jan./jun. 2011.

CASTRO, Rita de Almeida. Ser em cena, flor ao vento: etnografia de olhares híbridos. Brasília: Ed. UNB, 2012.

CAVALCANTI, Maria Laura Viveiros de Castro. Drama social: notas sobre um tema de Victor Turner. Cadernos de Campo, São Paulo, n. 16, p. 127-137, 2007.

CAVALCANTI, Maria Laura Viveiros de Castro. Luzes e sombras no dia social: o símbolo ritual em Victor Turner. Horizontes Antropológicos, Porto Alegre, a. 18, n. 37, 2012.

CAVALCANTI, Maria Laura Viveiros de Castro. Drama, ritual e performance em Victor Turner. Sociologia \& Antropologia, Rio de Janeiro, v. 3, n. 6, 2013.

CAVAlCANTI, Maria Laura Viveiros de Castro (org.). Ritual e Performance: 4 estudos clássicos. Rio de Janeiro: 7 Letras, 2014.

CLIFFORD, James; MARCUS, George. Writing Culture: the poetics and politics of ethnography. Berkley: University of California Press, 1986.

COELHO, Maria Cláudia Pereira. Teatro e contracultura: um estudo de antropologia social. 1989. Dissertação (Mestrado em Antropologia Social) - Programa de Pós-Graduação em Antropologia Social, Museu Nacional, Universidade Federal do Rio de Janeiro, Rio de Janeiro, 1989.

COHEN, Renato. Performance como Linguagem. Sáo Paulo: Perspectiva, 2002.

DAWSEY, John C.; MÜllER, Regina P.; HIKIJI, Rose Satiko G.; MONTEIRO, Marianna F. M. (org.). Antropologia e Performance: ensaios NAPEDRA. São Paulo: Editora Terceiro Nome, 2013.

DORT, Bernard. A representação emancipada. Sala Preta, São Paulo, v. 13, n. 1, p. 47-55, jun. 2013.

FÉRAL, Josette. Além dos limites: teoria e prática do teatro. São Paulo: Perspectiva, 2015.

FERNANDES, Silvia. Teatralidades contemporâneas. São Paulo: Ed. Perspectiva, 2013.

FERREIRA, Francirosy C. Barbosa; MÜllER, Regina Aparecida Pollo (org.). Performance, arte e antropologia. Sáo Paulo: Hucitec, 2010. 
GOFFMAN, Erving. Os quadros da experiência social: uma perspectiva de análise. Petrópolis: Ed. Vozes, 2012.

HARTMANN, Luciana; LANGDON, Esther Jean. Tem um corpo nessa alma: encruzilhadas da antropologia da performance no Brasil. BIB, São Paulo, n. 91, 2020.

HYMES, Dell. Breaktrough into performance In: BEN-AMOS, Dan; GOLDSTEIN, Kenneth S. (ed.). Folklore: performance and communication. The Hague: Mouton. 1977.

INGOLD, Tim. Chega de etnografia! A educação da atenção como propósito da antropologia. Educaçáo, Porto Alegre, v. 39, n. 3, p. 404-411, 2016.

INGOLD, Tim. Antropologia: para que serve? Petrópolis: Ed. Vozes, 2019.

KRÜGER, Cauê. Para além das canoas de papel. Cadernos de Campo, São Paulo, v. 17, n. 17, p. 75-87, 2008a.

KRÜGER, Cauê. Experiência Social e Expressáo Cômica: os parlapatôes, patifes e paspalhóes. 2008. Dissertação (Mestrado em Antropologia Social) - Programa de Pós-Graduação em Antropologia Social, Instituto de Filosofia e Ciências Humanas, Universidade Estadual de Campinas, Campinas, 2008b.

KRÜGER, Cauê. A arte do encontro: uma etnografia da companhia brasileira de teatro e do PROJETO bRASIL. 2017. Tese (Doutorado em Sociologia e Antropologia) - Programa de Pós-Graduação em Sociologia e Antropologia, Instituto de Filosofia e Ciências Sociais, Universidade Federal do Rio de Janeiro, Rio de Janeiro, 2017.

KRÜGER, Cauê. Discursos Deslocados, Imagens Evocadas. Iluminuras, Porto Alegre, v. 20, n. 48, p. 38-67, 2019.

LANGDON, Esther Jean. Performance e sua Diversidade como Paradigma Analítica: A Contribuição da Abordagem de Bauman e Briggs. Antropologia em Primeira Máo, Florianópolis, v. 94, p. 1-34, 2007.

LEIRIS, Michel. La possession et ses aspects théâtraux chez les Éthiopiens de Gondar. Paris: Librairie Plon, 1958.

MARIZ, Adriana. A ostra e a pérola: uma visão antropológica do corpo no teatro de pesquisa. Sáo Paulo: Ed. Perspectiva, 2007.

PAIS, Ana. O discurso da cumplicidade: dramaturgias contemporâneas. Lisboa: Colibri, 2016

PEIRANO, Mariza. O Dito e o Feito. Rio de Janeiro: Relume-Dumará, 2001. 
PEIRANO, Mariza. Temas ou Teorias? O estatuto das noçóes de ritual e performance. Campos, Curitiba, v. 2, n. 7, p. 9-16, 2006.

PRADIER, Jean-Marie. Ethnoscenologie: la chair de l'esprit. Paris: L'Harmattan, 1998.

RAPOSO, Paulo; CARDOSO, Vânia; DAWSEY, John; FRADIQUE, Teresa. A terra do não-lugar. Florianópolis: Ed. UFSC, 2013.

ROMAGNOLLI, Luciana Eastwood. Marés brasileiras: discursos em contrafluxos In: ABREU, Marcio. PROJETO bRASIL/Maré. Rio de Janeiro, Editora Cobogó, 2016. P. 85-93.

RYNGAERT, Jean-Pierre. Para ler o teatro contemporâneo. São Paulo: Ed. Martins Fontes, 2013.

SARRAZAC, Jean-Pierre. El impersonaje: Una relectura de La crisis del personaje. Literatura: teoría, historia, crítica, Bogotá, n. 8, 2006.

SARRAZAC, Jean-Pierre. Poética do drama moderno: de Ibsen a Koltés. São Paulo, Perspectiva, 2017.

SCHECHNER, Richard. Performance Theory. New York: Routlege, 1988.

SCHECHNER, Richard. Performance Studies: an introduction. New York: Ed. Routledge, 2003.

SILVA, Rubens Alves da. Entre artes e ciências: a noção de performance e drama no campo das ciências sociais. Horizontes Antropológicos, Porto Alegre, v. 11, n. $24,2005$.

SINGER, Milton. When a great traditions modernizes. New York: Praeger, 1972.

SZONDI, Peter. Teoria do Drama Moderno. São Paulo: Ed. Cosac \& Naify, 2001.

TOLEDO, Magdalena Sophia de. Antropologia e teatro: o grupo Ói Nóis Aqui Traveiz e $(\mathrm{m})$ Kassandra in process. Dissertação (Mestrado em Antropologia Social) - Programa de Pós-Graduação em Antropologia Social, Centro de Filosofia e Ciências Humanas, Universidade Federal de Santa Catarina, Florianópolis, 2007.

TORRES NETO, Walter Lima. Ensaios de Cultura Teatral. Jundiaí: Ed. Paco, 2016.

TURNER, Victor. Schism and Continuity in an African Society: a study of Ndembu Village Life. Manchester: Manchester University Press, 1957. 
TURNER, Victor. From Ritual to Theatre: the human seriousness of play. New York: PAJ Publications, 1982.

TURNER, Victor. The Anthropology of Performance. New York: PAJ Publications, 1988.

TURNER, Victor. Dramas, Campos e Metáforas. Niterói: Ed. UFF, 2008.

TURNER, Victor. O Processo Ritual. Petrópolis: Ed. Vozes, 2013.

TURNER, Victor. Do ritual ao Teatro: a seriedade humana de brincar. Rio de Janeiro: Ed. UFRJ, 2015.

TURNER, Victor; BRUNER, Edward (org.). The Anthropology of Experience. Urbana; Chicago: University of Illinois Press, 1986.

VAN GENNEP, Arnold. Os ritos de Passagem. Petrópolis: Ed. Vozes, 2011.

VASCONCELlOS, Luiz Paulo. Dicionário de Teatro. Porto Alegre: Ed. L\&PM, 2009.

Cauê Krüger holds a Doctoral degree in Sociology and Anthropology (UFRJ), a Master's degree in Social Anthropology from the State University of Campinas (UNICAMP), a Bachelor's degree in Theatre Arts from the Faculty of Arts of Paraná (FAP), and a Bachelor's degree in Social Sciences from the Federal University of Paraná (UFPR). Coordinator of the Specialization Course in Cultural Anthropology and Professor, Undergraduate Program in Social Sciences at the Catholic University of Paraná (PUCPR).

ORCID: https://orcid.org/0000-0002-0137-0121

E-mail: cauekruger@gmail.com

This original paper, translated by Paulo Palozi and Miriam Adelman, is also published in Portuguese in this issue of the journal.

Received on April 292020 Accepted on December 01, 2020

Editor-in-charge: Marcelo de Andrade Pereira

This is an open-access article distributed under the terms of the Creative Commons Attribution License 4.0 International. Available at: <http://creativecom mons.org/licenses/by/4.0>. 